\title{
Perancangan Film Pendek Animasi 3 Dimensi Legenda Desa Penyarang
}

\author{
Sitaresmi Wahyu Handani ${ }^{1}$, Devi Ratna Nafianti ${ }^{2}$ \\ ${ }^{1,2}$ Teknik Informatika, STMIK AMIKOM Purwokerto \\ ${ }^{1,2}$ Jl. Letjen Pol Sumarto, Purwanegara, Purwokerto Utara, Banyumas, Jawa Tengah 53123, INDONESIA \\ Email korespondensi : sita.handani@amikompurwokerto.ac.id
}

Dikirim 24 Maret 2017, Direvisi 28 April 2017, Diterima 21 Mei 2017

\begin{abstract}
Abstrak - Legenda merupakan cerita prosa rakyat, yang dianggap oleh empunya cerita sebagai suatu kejadian yang sungguh-sungguh pernah terjadi. Cerita rakyat adalah bagian dari kekayaan budaya dan sejarah yang dimiliki setiap bangsa. Cerita rakyat di Indonesia memiliki beragam cerita yang sangat menarik, salah satunya adalah Legenda desa Penyarang. Legenda desa Penyarang adalah salah satu cerita rakyat yang berasal dari desa Penyarang, kecamatan Sidareja, kabupaten Cilacap. Berdasarkan hasil survey yang dilakukan terhadap warga di kabupaten Cilacap didapatkan data bahwa beberapa masyarakat tidak mengetahui tentang legenda tersebut. Salah satu cara yang dapat dilakukan untuk memperkenalkan kembali cerita rakyat Legenda desa Penyarang kepada masyarakat adalah melalui film animasi. Penelitian ini menyajikan tentang perancangan animasi 3D tentang Legenda desa Penyarang dan dampaknya bagi masyarakat di sekitar desa tersebut setelah film animasi tersebut berhasil dibuat dan disosialisasikan. Ada tiga tahap penting dalam proses perancangan animasi 3D dalam penelitian ini yaitu Pra Produksi, Produksi, dan Pasca Produksi. Hasil akhir dari penelitian berupa video yang dapat digunakan tidak hanya untuk disosialisasikan di sekitar desa Penyarang, namun dapat digunakan secara lebih luas lagi.
\end{abstract}

Kata kunci - legenda, cerita rakyat, film animasi, 3D

Abstract - Legend of the prose stories of the people, who are considered by the source of the story as an event that truly never happened. Folklore is part of the rich culture and history of every nation. Folklore in Indonesia has a variety of very interesting story, one of which is the legend Penyarang village. Penyarang village legend is one of the folklore that came from the village Penyarang, sub Sidareja, Cilacap district. Based on the results of a survey of residents in Cilacap obtained the data that some people do not know about the legend. One way that can be done to reintroduce folklore legend Penyarang village to the community is through animation film. This study presents the design of three-dimensional animation of the village legend Penyarang and its impact on communities around the village after the animated film successfully created and disseminated. There are three important stages in the design process of 3D animation in this research Pre-Production, Production and Post-Production. The end result of the research is a video that can be used not only for dissemination around the area, but can be used more widely.

Keywords - legend, folklore, animation movie, 3D

\section{PENDAHULUAN}

Legenda merupakan cerita-cerita yang dianggap masyarakat pemiliknya sebagai peristiwa-peristiwa sejarah. Sebagian besar masyarakat menganggap bahwa legenda adalah sejarah rakyat [1]. Sedangkan menurut [2] legenda adalah prosa rakyat yang memiliki ciri-ciri yang mirip dengan mite, yaitu dianggap pernah benar-benar terjadi, tetapi tidak dianggap suci. Berbeda dengan mite, legenda ditokohi manusia, yang mempunyai kekuatan luar biasa, dan seringkali juga dibantu makhluk-makhluk ajaib.

Legenda desa Penyarang adalah salah satu cerita rakyat yang berasal dari desa Penyarang, kecamatan Sidareja, kabupaten Cilacap. Legenda desa Penyarang berkisah tentang asal-usul berdirinya desa Penyarang. Tokoh utama Legenda desa Penyarang adalah Patih Ranggasena yang berasal dari Sunda. Dalam cerita disebutkan bahwa dahulu desa Penyarang pernah menjadi salah satu kadipaten Kerajaan Mataram. 
Dari penelitian sebelumnya yang dilakukan oleh [3] dapat disimpulkan bahwa pada masa sekarang ini, media komunikasi visual seperti film dan tayangan televisi sangat digemari remaja. Media audio visual mempunyai peran efektif untuk menjangkau komunikasi dan edukasi masyarakat khususnya generasi muda. Pengembangan audio visual dengan kemasan dan tampilan keseluruhan yang menarik akan lebih membangkitkan minat dari target audience yang dalam hal ini khususnya adalah para remaja terhadap produk-produk film animasi lokal. Sehingga pesan moral yang ingin disampaikan dapat diterima dengan lebih mudah oleh para remaja.

Penelitian lain yang dilakukan oleh [4] menyimpulkan bahwa komunikasi menggunakan media audio visual sangatlah berguna dan efektif untuk menjangkau masyarakat. Pengembangan audio visual dengan kemasan dan keseluruhan yang menarik akan lebih membangkitkan minat dari target audience yang dalam hal ini khususnya adalah anak-anak, sehingga pesan moral yang ingin disampaikan pun dapat diterima dengan lebih mudah oleh anak-anak. Sehingga dengan adanya pembuatan film pendek animasi dengan tema cerita rakyat akan membantu perkembangan animasi lokal di Indonesia. Maka dengan tema sederhana, lokal dan mencerminkan serta memperkenalkan budaya Indonesia seperti cerita rakyat, apabila dibuat dengan menarik seperti dengan teknologi 3 dimensi (3D), maka diharapkan masyarakat dapat memetik hal positif dari film animasi pendek cerita rakyat.

Berkaitan dengan hal teknis perancangan animasi 3D, menurut [5] ada tiga tahapan penting dalam pembuatan animasi, yaitu pra produksi, produksi, dan pasca produksi. Tiga tahapan ini merupakan tahap dalam proses perancangan animasi yang umum dilakukan baik untuk perancangan animasi 2D dan 3D. Menurut [6] dari ketiga tahapan tersebut tahap produksi merupakan tahap sebenarnya (inti) dalam pembuatan film animasi 3D.

\section{METODE PENELITIAN}

\section{A. Metode Pengumpulan Data}

Pengumpulan data dilakukan bertujuan untuk mendapatkan data dan informasi terkait perancangan film animasi 3D legenda desa Penyarang. Data dan informasi tersebut didapat melalui.

\section{a) Observasi}

Observasi atau pengamatan (observation) merupakan salah satu teknik pengumpulan fakta atau data (fact finding technique) yang cukup efektif untuk mempelajari suatu sistem. Observasi dilakukan dengan melakukan pengamatan secara langsung untuk mencari data-data yang relevan terkait legenda desa Penyarang di desa tersebut.

\section{b) Wawancara}

Wawancara adalah komunikasi dua arah untuk mendapatkan data dari responden. Wawancara dilakukan untuk menggali informasi terkait Legenda Desa Penyarang, wawancara dilakukan kepada warga sekitar, penjaga makam Adipati
Ranggasena, dan juga Pemda Kabupaten Cilacap, Dinas Pariwisata dan Kebudayaan.

c) Studi Pustaka

Studi pustaka dilakukan dalam rangka mencari literature review seputar perancangan animasi 3D, juga hal yang berkaitan dengan legenda atau cerita rakyat melalui media multimedia.

d) Kuisoner (Angket)

Kuesioner dibagikan ke 30 responden dimana angka ini mewakili tiga kelompok masyarakat yaitu anak-anak - remaja, dewasa, dan orang tua. Kuesioner atau pengambilan sampel dilakukan sebelum dan sesudah penelitian guna mengetahui respon masyarakat di sekitar desa Penyarang tentang cerita Legenda Desa Penyarang sebelum dan sesudah dirancangnya film animasi 3D.

\section{B. Metode Perancangan Film Animasi 3D}

Metode yang digunakan dalam merancang film animasi 3D menggunakan konsep yang biasa digunakan oleh industri animasi pada umumnya, yaitu melalui tiga tahapan sebagai berikut.

a) Pra Produksi

Pada tahap ini, peneliti bekerjasama dengan tim melakukan proses penggalian ide dan konsep, penulisan scenario / script, pembuatan sketsa model atau blueprint, perancangan storyboard dan pengambilan material suara untuk keperluan backsound.

b) Produksi

Tahap produksi dimulai dengan pembuatan model 3D untuk keperluan film, yaitu pembuatan objek 3D karakter dan objek 3D pendukung (environment). Setelah itu dilanjutkan dengan pemberian material dan texture pada object 3D yang telah selesai dibuat. Tahap selanjutnya adalah pemilihan dan penggunaan lighting / cahaya pada scene yang telah dibuat. Setelah itu dilanjutkan dengan pemberian effect terhadap environment yang telah dibuat. Setelah semua object selesai dibuat lengkap dengan material dan effect-nya, langkah selanjutnya adalah menganimasikan masing-masing karakter sesuai dengan peran mereka dalam cerita Legenda Desa Penyarang. Setelah animate selesai, langkah akhir dalam fase ini adalah rendering.

c) Pasca Produksi

Kegiatan pada tahap ini meliputi: editing animation and voice, compositing and visual effect, adding sound and audio/folley, preview and final, dan burn to tape/CD.

\section{Metode Pengujian}

Tahap akhir dalam penelitian ini adalah pengujian. Pengujian dilakukan dua tahap, yaitu pengujian alpha dan beta. Alpha testing dilakukan untuk memastikan sudah tidak ada kekeliruan dan kesalahan secara teknis dalam pembuatan film animasi 3D ini. Sedangkan beta testing dilakukan kepada pihak ahli yang mengetahui tentang Legenda Desa Penyarang, Beta testing 
dilakukan sebagai bentuk konfirmasi bahwa materi dalam film yang dibuat sudah sesuai dengan cerita Legenda Desa Penyarang.

\section{HASIL DAN PEMBAHASAN}

\section{Hasil Penelitian}

Hasil dari penelitian ini berupa film animasi 3D yang menceritakan tentang Legenda Desa Penyarang. Film ini dikemas dalam bentuk $\mathrm{CD}$ yang akan dibagikan ke masyarakat sekitar desa Penyarang, juga berbentuk file video yang akan diunggah di media sosial (Youtube). Selesai pembuatan film animasi 3D, dilakukan pengujian dengan membagikan kuisoner ke warga sekitar desa Penyarang. Pembagian kuisoner ini bertujuan untuk mendapatkan penilaian dan melihat repson dari masyarakat dengan adanya perancangan film animasi 3D Legenda Desa Penyarang.

\section{E. Pembahasan}

Berikut ini adalah gambaran umun desa Penyarang dan tahapan perancangan film animasi 3D Legenda Desa Penyarang.

a) Gambaran Umum Desa Penyarang

Desa Penyarang merupakan bagian dari wilayah perbatasan Jawa Tengah dan Jawa Barat dan bertempat di Kecamatan Sidareja Kabupaten Cilacap, yang secara geografis berada di dataran tinggi. Desa Penyarang memiliki jumlah penduduk sekitar \pm 7.024 orang. Desa Penyarang lebih dikenal dengan tempat ziarah (panembahan) dan wisata alam.

b) Perancangan Film Animasi 3D Legenda desa Penyarang

1. Pra Produksi

a. Ide Cerita dan Konsep

Ide cerita dan konsep dalam perancangan film animasi 3D Legenda Desa Penyarang peneliti sesuaikan dengan naskah asli yang didapatkan dari Dinas Pariwisata dan Kebudayaan Pemda Cilacap.

b. Penulisan Skenario

Penulisan skenario disesuaikan dengan naskah asli yang diperoleh dari Dinas Pariwisata dan Kebudayaan Pemda Cilacap.

c. Pembuatan Sketsa Model / Blueprint Berikut ini adalah sketsa atau blueprint dua karakter yang terlibat dalam cerita Legenda Desa Penyarang:

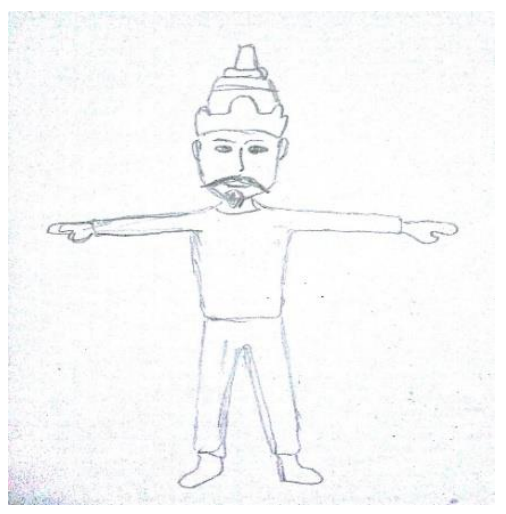

Gambar 1. Prabu Ciung Wanara

Gambar 1 merupakan gambar blueprint atau sketsa dari karakter Prabu Ciung Wanara. Blueprint ini yang dijadikan referensi dalam pembuatan model 3D film animasi yang dibuat. Prabu Ciung Wanara merupakan seorang raja berusia 55 tahun, mempunyai sifat baik dan tegas, dengan kulit berwarna putih dan berambut warna hitam pendek dan berkumis. Prabu Ciung Wanara adalah ayah dari Ranggasena.

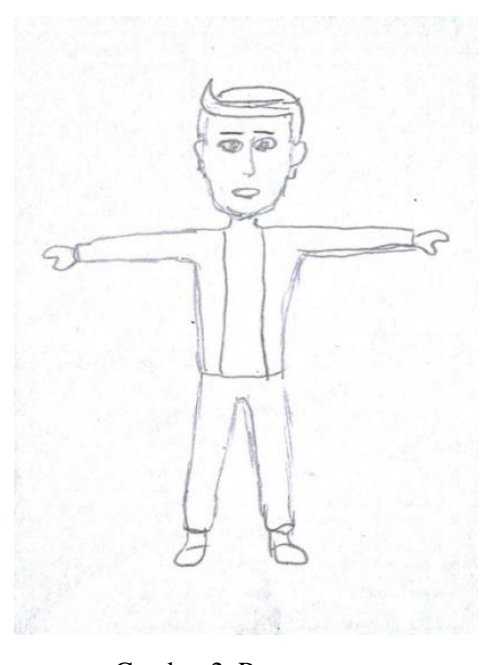

Gambar 2. Ranggasena

Gambar 2 merupakan blueprint dari karakter Ranggasena. Ranggasena adalah pria 35 tahun, mempunyai sifat baik, tangguh dan ulet, dengan kulit berwarna putih dan berambut warna hitam pendek juga berikat kepala asli Sunda. Ranggasena merupakan tokoh utama dalam film animasi 3D Legenda Desa Penyarang.

d. Storyboard

Storyboard dirancang sebagai acuan dalam proses produksi, menyajikan dialog dan adegan tiap scene dalam film animasi 3D Legenda Desa Penyarang.

e. Audio Collecting

Tahap ini peneliti melakukan proses perekaman suara yang akan digunakan dalam film animasi 3D. 


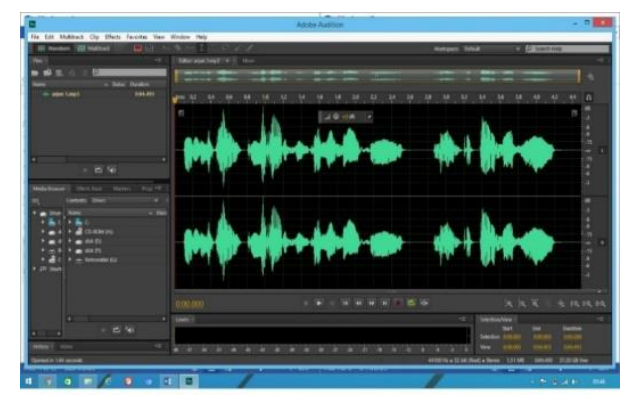

Gambar 3. Proses pengambilan dan editing suara

Gambar 3 menunjukkan proses pengambilan audio dan editing audio menggunakan software Adobe Audition untuk mendapatkan suara yang jernih dan berkualitas. File hasil rekaman disimpan dengan format file .mp3 untuk memudahkan proses berikutnya.

2. Produksi

a. Modeling \& Texturing

Proses yang pertama kali dilakukan pada tahap produksi adalah modeling dan texturing [7]. Pada tahap ini peneliti membuat berbagai macam model 3D dan pemberian texture pada objek 3D yang telah dibuat.

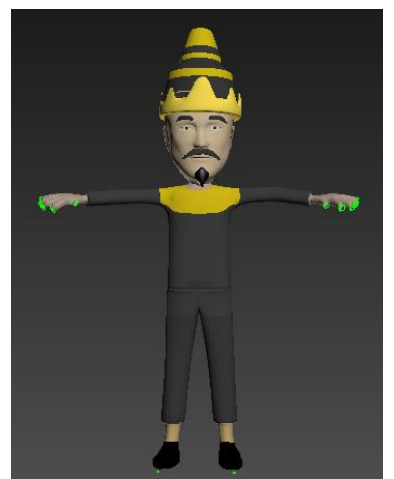

Gambar 4. Model 3D Prabu Ciung Wanara

Gambar 4 merupakan hasil pemodelan 3D untuk karakter Prabu Ciung Wanara. Karakter 3D Prabu Ciung Wanara dibuat menyesuaikan sketsa / blueprint yang telah dibuat sebelumnya (Gambar 1).

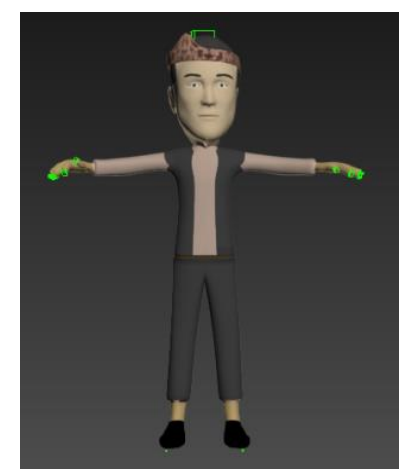

Gambar 5. Model 3D Ranggasena
Gambar 5 merupakan hasil pemodelan 3D untuk karakter Ranggasena. Karakter 3D Ranggasena dibuat menyesuaikan sketsa / blueprint yang telah dibuat sebelumnya (gambar 2).

b. Lighting

Pada tahap dilakukan proses pencahayaan / lighting.

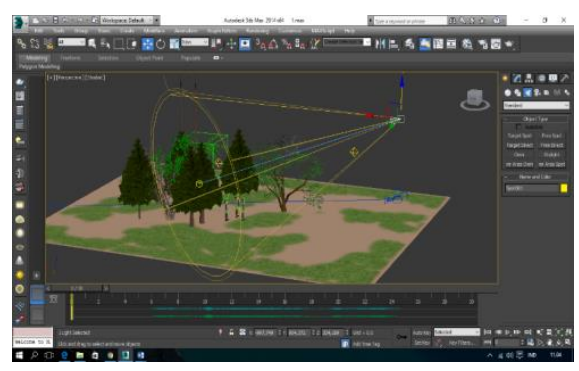

Gambar 6. Proses Penataan Cahaya

Gambar 6 merupakan proses peletakan lighting atau pencahayaan menggunakan target spot yang disesuaikan pada objek yang akan diberi cahaya.

c. Environment Effect

Proses pengaturan environment effect bertujuan untuk mendapatkan latar film animasi yang realistis, enak dipandang serta mendukung isi cerita yang dianimasikan [8].

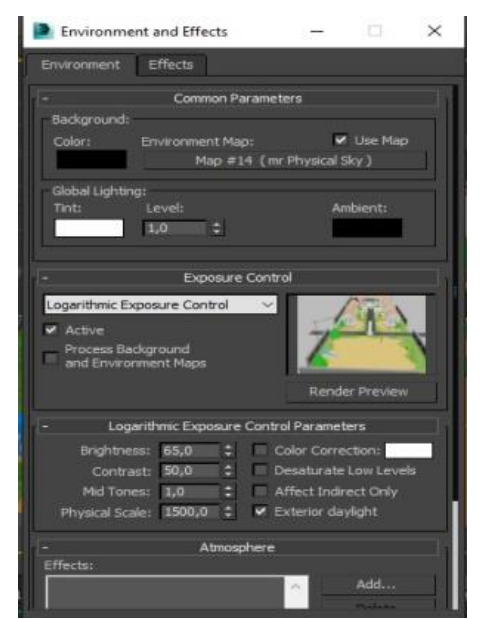

Gambar 7. Pengaturan Environment Effect

Gambar 7 menunjukkan proses pengaturan environment effect pada salah satu scene dalam film animasi 3D Legenda Desa Penyarang.

d. Animation

Proses ini dapat dilakukan setelah model yang telah melalui proses rigging dan skinning. Animate (animation) adalah proses menggerakan objek 3D pada sebuah aplikasi [9]. 


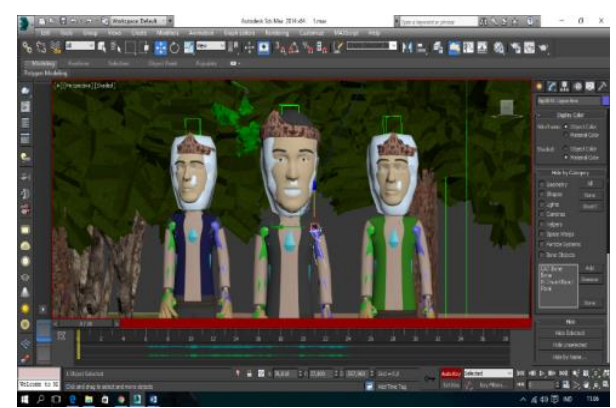

Gambar 8. Proses Animasi

Gambar 8 merupakan proses pergerakan karakter dan objek 3D, biasa disebut dengan animation. Proses animate dilakukan dengan cara memilih auto key dan mengatur frame untuk menyimpan pergerakan saat mengubah tangan, kaki, tubuh, kepala dan pergerakan objek lainnya.

e. Rendering

Tahap akhir dari proses produksi adalah proses rendering [10].

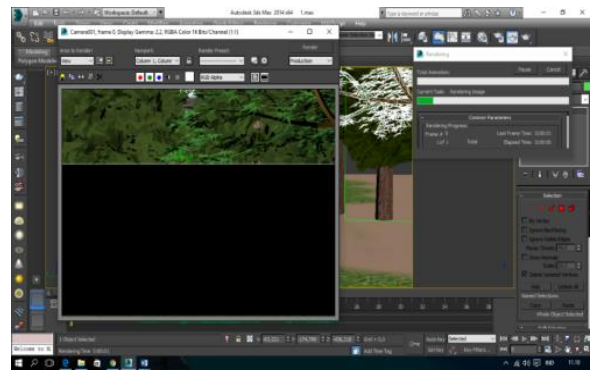

Gambar 9. Proses Rendering

Gambar 9 memperlihatkan proses rendering objek dan animasi 3D yang telah dibuat menggunakan software Autodesk 3Ds Max. Proses ini menghasilkan output berupa video yang nantinya akan dilakukan editing lagi dalam proses pasca produksi.

3. Pasca Produksi

a. Editing Animation and Voice

Dalam proses ini animasi yang sudah dirender dilakukan editing, berupa pembuangan gerakan atau adegan yang tidak dibutuhkan. Dalam proses ini audio di edit dan dicocokan sesuai kebutuhan.

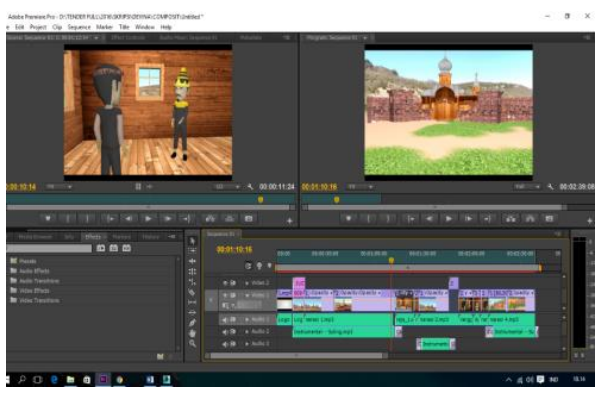

Gambar 10. Proses Editing Animation and Voice
Gambar 10 menunjukkan proses editing animation and voice menggunakan aplikasi Adobe Premiere Pro CC.

b. Compositing and Visual Effect

Tahap ini berfungsi untuk menyatukan antara hasil render gambar dan video yang dihasilkan, kemudian dilakukan proses penyusunan sesuai dengan urutan animasi yang sesuai dengan storyboard / naskah yang telah dibuat.

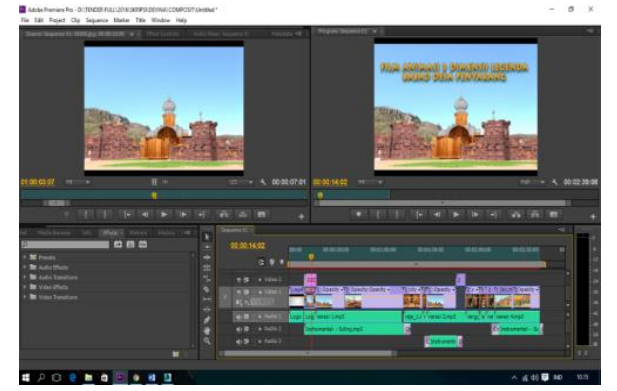

Gambar 11. Proses Composite and Visual Effect

Gambar 11 menunjukkan proses compositing dan pemberian visual effect pada beberapa scene film animasi 3D yang sedang dibuat.

c. Adding Sound and Audio

Pada tahap ini suara ditambahkan untuk memperkuat efek visual dari film animasi tersebut. Penambahan suara dapat berupa penambahan SFX (Sound Effect) dan musik yang akan memperkuat film animasi tersebut.

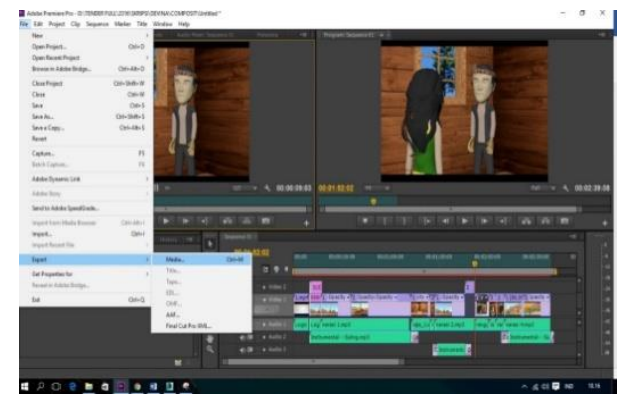

Gambar 12. Proses Penambahan Sound \& Audio

Gambar 12 menunjukkan proses penambahan sound dan audio menggunakan software Adobe Premiere Pro CC.

d. Preview and Final

Tahap ini merupakan proses akhir yaitu penyatuan dari keseluruhan pembuatan Film Animasi 3D Legenda Desa Penyarang. Di dalam proses ini mulai dari video, audio dan compositing disatukan menjadi film animasi secara utuh.

e. Burn to Tape

Proses ini merupakan tahap akhir dari perancangan film animasi 3D. Setelah film berhasil kemudian disimpan dalam media CD/DVD. Selain di-burning ke dalam 
CD/DVD film ini juga diunggah ke media youtube.

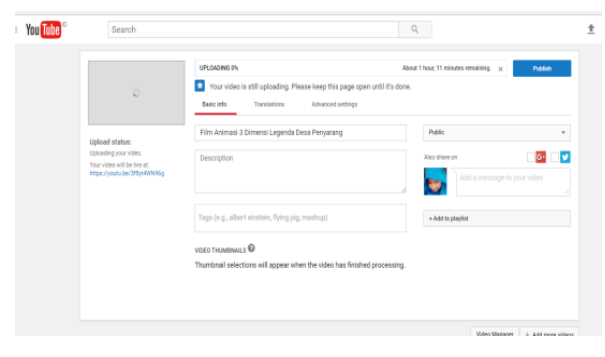

Gambar 13. Proses Unggah Ke Situs Youtube

Gambar 13 menunjukkan proses unggah video animasi 3D Legenda Desa Penyarang ke jejaring sosial media Youtube.

\section{F. Hasil Pengujian}

Setelah proses perancangan film animasi 3D selesai, langkah selanjutnya adalah melakukan proses pengujian.

a) Pengujian alpha

Alpha test dilakukan dengan menguji secara teknis untuk menguji apakah ada kesalahan dalam perancangan animasi 3D atau tidak. Pengujian ini meliputi pengujian dari visualisasi $3 \mathrm{D}$ dan juga pengecekan audio sudah tepat atau belum. Dari hasil pengujian yang dilakukan didapatkan hasil bahwa film animasi 3D Legenda Desa Peyarang secara teknis tidak bermasalah dan dapat dilanjutkan untuk proses berikutnya, yaitu pengujian beta.

b) Pengujian beta

Berikut adalah tabel daftar pertanyaan untuk pengujian beta.

\begin{tabular}{|c|c|c|c|c|c|c|}
\hline \multirow{2}{*}{ No } & \multirow{2}{*}{ ASPEK } & \multicolumn{5}{|c|}{ PENILAIAN } \\
\hline & & SS & ST & RG & TS & STS \\
\hline 1 & $\begin{array}{l}\text { Tampilan film animasi } \\
\text { menarik }\end{array}$ & & & & & \\
\hline 2 & $\begin{array}{l}\text { Pemakaian komposisi } \\
\text { warna sudah tepat }\end{array}$ & & & & & \\
\hline 3 & $\begin{array}{l}\text { Film animasi 3D Legenda } \\
\text { Desa Penyarang menarik } \\
\text { untuk dilihat. }\end{array}$ & & & & & \\
\hline 4 & $\begin{array}{l}\text { Gerakan animasi pada } \\
\text { setiap adegan sudah } \\
\text { layak. }\end{array}$ & & & & & \\
\hline 5 & $\begin{array}{l}\text { Pesan yang disampaikan } \\
\text { cukup mudah dipahami } \\
\text { maksudnya } \\
\text { Film animasi 3D Legenda }\end{array}$ & & & & & \\
\hline 6 & $\begin{array}{l}\text { Desa Penyarang baik } \\
\text { untuk ditampilkan. }\end{array}$ & & & & & \\
\hline
\end{tabular}

Tabel 2. Persentase Nilai

\begin{tabular}{cc}
\hline Nilai & Keterangan \\
\hline $80 \%-100 \%$ & Sangat Setuju \\
$60 \%-79,99 \%$ & Setuju \\
$40 \%-59,99 \%$ & Ragu - Ragu \\
$20 \%-39,99 \%$ & Tidak Setuju \\
$0 \%-19,99 \%$ & Sangat Tidak Setuju \\
\hline
\end{tabular}

Pengujian beta dilakukan dengan memberikan pertanyaan tersebut pada tabel 1 kepada 30 repsonden yang beralamat di sekitar desa Penyarang. Dari hasil penyebaran kuisoner didapatkan hasil sebagai berikut.

\section{Aspek Pengujian 1}

Tabel 3. Aspek Pengujian 1

\begin{tabular}{cc}
\hline Jawaban & Jumlah \\
\hline Sangat Setuju & 9 \\
Setuju & 20 \\
Ragu - Ragu & 1 \\
Tidak Setuju & 0 \\
Sangat Tidak Setuju & 0 \\
Total & $\mathbf{3 0}$ \\
\hline
\end{tabular}

$\begin{array}{ll}\text { Skor SS } & =9 \times 5=45 \\ \text { Skor S } & =20 \times 4=80 \\ \text { Skor RG } & =1 \times 3=3 \\ \text { Skor TS } & =0 \times 2=0 \\ \text { Skor STS } & =0 \times 1=0 \quad+ \\ \text { Jumlah } & =\mathbf{1 2 8}\end{array}$

Jumlah skor ideal untuk seluruh item $=5 \times 30=$ 150 (seandainya semua menjawab SS). Jumlah skor yang diperoleh dari penelitian $=128$. Jadi berdasarkan data itu maka tingkat persetujuan terhadap aspek pengujian ke $-1=(128: 150) \mathrm{x}$ $100 \%=85.3 \%$ (Sangat Setuju) dari yang diharapkan (100\%).

2. Aspek Pengujian 2

Tabel 4.Aspek Pengujian 2

\begin{tabular}{cc}
\hline Jawaban & Jumlah \\
\hline Sangat Setuju & 7 \\
Setuju & 20 \\
Ragu - Ragu & 3 \\
Tidak Setuju & 0 \\
Sangat Tidak Setuju & 0 \\
Total & $\mathbf{3 0}$ \\
\hline
\end{tabular}

Skor SS $=7 \times 5=35$

Skor $\mathrm{S}=20 \times 4=80$

Skor RG $=3 \times 3=9$

Skor TS $=0 \times 2=0$

$\underline{\text { Skor STS }=0 \times 1=0+}$ skor 5

skor 4

skor 3

skor 2

skor 1 
Jumlah skor ideal untuk seluruh item $=5 \times 30=$ 150 (seandainya semua menjawab SS). Jumlah skor yang diperoleh dari penelitian $=124$. Jadi berdasarkan data itu maka tingkat persetujuan terhadap aspek pengujian ke $-2=(124: 150) \mathrm{x}$ $100 \%=82.6 \%$ (Sangat Setuju) dari yang diharapkan (100\%).

\section{Aspek Pengujian 3}

Tabel 5. Aspek Pengujian 3

\begin{tabular}{cc}
\hline Jawaban & Jumlah \\
\hline Sangat Setuju & 13 \\
Setuju & 15 \\
Ragu - Ragu & 2 \\
Tidak Setuju & 0 \\
Sangat Tidak Setuju & 0 \\
Total & $\mathbf{3 0}$ \\
\hline
\end{tabular}

Skor SS $=13 \times 5=65$

Skor $S=15 \times 4=60$

Skor RG $=2 \times 3=6$

Skor TS $=0 \times 2=0$

$\underline{\text { Skor STS }=0 \times 1=0+}$

Jumlah = 131

Jumlah skor yang diperoleh dari penelitian = 131. Jadi berdasarkan data itu maka tingkat persetujuan terhadap aspek pengujian ke $-3=$ $(131: 150) \times 100 \%=87.3 \%$ (Sangat Setuju) dari yang diharapkan (100\%).

\section{Aspek Pengujian 4}

Tabel 6. Aspek Pengujian 4

\begin{tabular}{cc}
\hline Jawaban & Jumlah \\
\hline Sangat Setuju & 12 \\
Setuju & 15 \\
Ragu - Ragu & 3 \\
Tidak Setuju & 0 \\
Sangat Tidak Setuju & 0 \\
Total & $\mathbf{3 0}$
\end{tabular}

\begin{tabular}{l} 
Skor SS $=12 \times 5=60$ \\
Skor S $=15 \times 4=60$ \\
Skor RG $=3 \times 3=9$ \\
Skor TS $=0 \times 2=0$ \\
Skor STS $=0 \times 1=0+$ \\
\hline Jumlah
\end{tabular}

Jumlah skor yang diperoleh dari penelitian = 129. Jadi berdasarkan data itu maka tingkat persetujuan terhadap aspek pengujian ke $-4=$ $(129: 150) \times 100 \%=86 \%$ (Sangat Setuju) dari yang diharapkan $(100 \%)$.

\section{Aspek Pengujian 5}

Tabel 7. Aspek Pengujian 5

\begin{tabular}{cc}
\hline Jawaban & Jumlah \\
\hline Sangat Setuju & 5
\end{tabular}

\begin{tabular}{cc}
\hline Jawaban & Jumlah \\
\hline Setuju & 21 \\
Ragu - Ragu & 4 \\
Tidak Setuju & 0 \\
Sangat Tidak Setuju & 0 \\
Total & $\mathbf{3 0}$ \\
\hline
\end{tabular}

$\begin{array}{ll}\text { Skor SS } & =5 \times 5=25 \\ \text { Skor S } & =21 \times 4=84 \\ \text { Skor RG } & =4 \times 3=12 \\ \text { Skor TS } & =0 \times 2=0 \\ \text { Skor STS } & =0 \times 1=0+ \\ \text { Jumlah } & =\mathbf{1 2 1}\end{array}$

Jumlah skor yang diperoleh dari penelitian = 121. Jadi berdasarkan data itu maka tingkat persetujuan terhadap aspek pengujian ke $-5=$ $(121: 150) \times 100 \%=80.6 \%$ ( Setuju) dari yang diharapkan $(100 \%)$.

6. Aspek Pengujian 6

Tabel 8. Aspek Pengujian 6

\begin{tabular}{cc}
\hline Jawaban & Jumlah \\
\hline Sangat Setuju & 13 \\
Setuju & 16 \\
Ragu - Ragu & 1 \\
Tidak Setuju & 0 \\
Sangat Tidak Setuju & 0 \\
Total & $\mathbf{3 0}$ \\
\hline
\end{tabular}

\begin{tabular}{|c|c|c|}
\hline Skor SS & $=13 \times 5$ & $=65$ \\
\hline Skor S & $=16 \times 4$ & $=64$ \\
\hline Skor RG & $=1 \times 3$ & $=3$ \\
\hline Skor TS & $=0 \times 2$ & $=0$ \\
\hline Skor STS= & $=0 \times 1$ & $=0 \quad+$ \\
\hline Jumlah & & $=132$ \\
\hline
\end{tabular}

Jumlah skor yang diperoleh dari penelitian = 132. Jadi berdasarkan data itu maka tingkat persetujuan terhadap aspek pengujian ke $-6=$ (132: 150) x $100 \%=88 \%$ (Sangat Setuju) dari yang diharapkan (100\%).

Dari hasil tersebut dapat disimpulkan bahwa pada Film Animasi 3D Legenda Desa Penyarang. Sebagai Media sosialisasi melestarikan budaya dan mengenalkan kembali cerita lokal sudah layak untuk digunakan.

\section{PENUTUP}

\section{A. Kesimpulan}

Penelitian tentang perancangan film animasi 3D Legenda Desa Penyarang telah selesai dilakukan. Hasil dari penelitian berupa video animasi 3D Legenda Desa Penyarang dalam format mp4 yang dikemas dalam bentuk CD dan juga diunggah ke situs Youtube. Dari survey yang dibagikan kepada masyarakat sekitar desa Penyarang didapatkan kesimpulan bahwa media 
animasi 3D ini cukup layak digunakan sebagai media pengenalan kembali cerita atau Legenda Desa Penyarang.

\section{B. Saran}

Penelitian ini masih terbatas pada bagaimana Legenda Desa Penyarang dirancang menggunakan animasi 3D. Penelitian ini belum membahas lebaih detail tentang detail texture yang digunakan, proses efisisensi rigging \& skinning, serta belum dibahas tentang teknik animasi yang digunakan. Harapan ke depannya akan ada penelitian yang membahas lebih detail khusus tentang pemodelan 3D yang digunakan, texture hingga animasi dan pengeditan sound/audio yag digunakan dalam merancang film animasi 3D Legenda Desa Penyarang.

\section{DAFTAR PUSTAKA}

[1] Hutomo, Suripan, Sadi. Mutiara yang Terlupakan. Malang: Dioma.1991.

[2] James Danandjaja, Folklore Indonesia, Ilmu Gosip, Dongeng, dan Lain lain. Jakarta: Pustaka Utama Grafiti, 2002.

[3] Suryajaya, Pamela, and Dyah Gayatri Puspitasari. "Perancangan Komunikasi Visual Film Animasi Pendek
"Dewi Yang Kesepian"." Humaniora 2.1 (2011): 608619.

[4] Wijaya, Fenny, and Dyah Gayatri Puspitasari. "Perancangan Komunikasi Visual Film Animasi Pendek "Sitiha Dan Sisiti"." Humaniora 1.2 (2010): 489-500.

[5] Handani, Sitaresmi Wahyu, Shima Utami, and Dinar Kusmira. "Visualisasi Pencemaran Air Menggunakan Media Animasi Infografis." Telematika 10.1 (2017).

[6] Syahfitri, Yunita. "Teknik Film Animasi Dalam Dunia Komputer." Journal Saintikom 10 (2011).

[7] Handani, S.W., Suyanto, M. and Sofyan, A.F., Penerapan Konsep Gamifikasi Pada E-Learning Untuk Pembelajaran Animasi 3D. Telematika, 9(1). 2016.

[8] Aditya. Trik Dahsyat Menjadi Animator 3D Andal. Yogyakarta : Andi Offset. 2009

[9] Apriyani, Meyti Eka; Gustianto, Robie. Augmented Reality sebagai Alat Pengenalan Hewan Purbakala dengan Animasi 3D menggunakan Metode Single Marker. JURNAL INFOTEL, [S.1.], v. 7, n. 1, p. 47-52, may 2015

[10] Ahmed, Satish. 3D Animation: Don't Drink and Drive. International Journal Service,Science and Technology Vol.8, No.1. 2015 